\title{
Perspektiva životnog puta u istraživanjima starenja i migracija
}

\author{
DOI: https://doi.org/10.11567/met.36.2.1 \\ UDK: $303.686: 159.922 .63$ \\ 303.686:314.151.3-054.7 \\ Pregledni rad \\ Primljeno: 7.12.2020. \\ Prihvaćeno: 24.2.2021.
}

\section{Sonja Podgorelec}

Znanstveni odsjek za migracijska i demografska istraživanja, Institut za migracije $i$ narodnosti, Zagreb

sonja.podgorelec@imin.hr

\section{SAŽETAK}

Razlozi izbora teme ovoga rada jesu ubrzano starenje stanovništva Hrvatske i znatne migracije, seljenje unutar zemlje, iseljavanje, ali i doseljavanje sve više stranaca. Cilj rada jest vrednovati prednosti i nedostatke istraživanja starenja (kvalitete života starih ljudi) i migracija (kvalitete života migranata) iz perspektive životnog puta pregledom nekih od važnijih radova koji se time bave, podjednako teorijski i/ili primijenjeno. Perspektiva životnog puta (life course perspective) složen je pristup istraživanja života pojedinca ili skupina odnosno određenih procesa. Prema raznim autorima, perspektiva životnog puta povezuje povijesni kontekst koji određuje pojedinčev život $s$ osobnom povijesti (ključnim događajima njegova života) (Edmonston, 2013; Holman i Walker, 2020). Analizirajući više desetaka radova, autorica nastoji pokazati primjenjivost na istraživanja vezana uz starenje populacije i procjenu kvalitete života te stupanj integracije imigranata u zemlju primitka. Pritom, objašnjavajući metode prikupljanja podataka u različitim istraživanjima, pomnije raščlanjuje prednosti uporabe biografske metode (životne priče, životne povijesti) (Atkinson, 1998; Shanahan i Macmillan, 2008). Naime, istraživanja kvalitete života starih ljudi moraju biti utemeljena na teorijskoj konstrukciji starenja i povijesnom kontekstu, oslanjajući se na podatke o bitnim životnim događajima pojedinca i prosudbama iskustava ispitanika i istraživača, jednako kao i istraživanja kvalitete života migranata. Kao i starenje, i migracije su uvijek politički, društveno i gospodarski uvjetovane te specifične s obzirom na jedinstvenost života svakog migranta, odnosno pojedinčeve životne priče. Pregledom odabrane literature posvećene istraživanjima starenja i migracijama kao dvama odvojenim procesima, ali promatranima iz iste perspektive, moguće je zaključiti da dijele slične putanje, prijelaze, prekretnice i vrijeme (Edmonston, 2013).

KLJUČNE RIJEČI: perspektiva životnog puta, starenje, migracije, životna priča 


\section{UVOD}

Perspektiva životnog puta $^{1}$ (life-course perspective) složen je pristup istraživanja života pojedinca ili skupina odnosno određenih procesa koji se upotrebljava u raznim disciplinama (Börsch-Supan i sur., 2013), a posebice u sociologiji, demografiji, psihologiji i ekonomiji. Prema Dannefer i Miklowski (2006: 31), tri su razine u analizi životnog puta: individualni, koji je odraz proživljenih iskustava pojedinaca (psihologija), kolektivni, koji oslikava iskustva pojedine kohorte (demografija) ili drugih skupina ${ }^{2}$ (sociologija, ekonomija), a rezultat je društvenih promjena i društvene strukture, te sociokulturni ili simbolički, koji analizira životni put kao konstrukt sam po sebi. Takav koncept, tumače autori, analizira društvo u cjelini baveći se idejama, normativnim okvirom (očekivanjima) i društvenom praksom.

Perspektivom životnog puta nastoji se povezati povijesni kontekst koji određuje pojedinčev život s osobnom povijesti (ključnim događajima njegova života) (Edmonston, 2013; Holman i Walker, 2020). Taj se pristup potvrdio kao valjan u ranim istraživanjima demografije obitelji, socioekonomskih promjena i obiteljske stabilnosti (Glick, 1988), a primjenjuje se i danas upravo zbog složenih promjena koje je u proteklih šezdesetak godina doživjela suvremena obitelj ${ }^{3}$ (Akrap i Čipin, 2006). Također, pokazao se korisnim i u ranim istraživanjima migracija (Thomas i Znaniecki, 1958), preciznije života migranata u novoj društvenoj okolini, pri čemu su se istraživači vrlo često koristili biografskom metodom. Perspektivu životnog puta pri istraživanju određenih životnih stadija stanovništva (primjerice starosti) (Hughes, 1990; Wanka, 2019) ili velikih životnih odluka koje dovode do znatnih promjena u životu pojedinca (primjerice migracije) (Amit i Bar-Lev, 2010; Edmonston, 2013) istraživači rabe kako bi pronašli povezanost s ranijim događajima tijekom života pojedinca koji su utjecali na njihove kasnije odluke, izbore i kvalitetu života, tj. zadovoljstvo životom (Podgorelec, 2008; Amit i Litwin, 2010; Podgorelec, Gregurović i Klempić Bogadi, 2015).

Prema Edmonstonu (2013: 2-3), perspektivu životnog puta određuju putanje, prijelazi, prekretnice i vrijeme. Putanje, primjerice istraživanje nečije

1 Istraživači primjenjuju i koncepte životnog ciklusa (life-cycle perspective) te životnog trajanja (life-span perspective), što će biti objašnjeno u radu.

2 Primjerice migranti, baveći se pitanjima raznih aspekata integracije u društvo primitka, pozicije na tržištu rada, doznaka i sl.

3 Uporaba pristupa životnog puta u istraživanjima izvanbračnih zajednica, jednoroditeljskih obitelji, raznih odnosa nakon razvoda (prekida partnerstva), života odrasle djece u zajedničkom kućanstvu s ostarjelim roditeljima i sl. 
karijere, čine dugotrajni obrasci promjene i stabilnosti. Prijelazi su životni događaji koji mogu uzrokovati promjene u životu i odnosima pojedinca (gubitak ili promjena posla). Prekretnice su značajni prijelazi koji uzrokuju nagle promjene putanje životnog tijeka pojedinca (umirovljenje). Vremenski okvir je, s jedne strane, povijesni kontekst koji utječe na životnu putanju, ali i određeni događaji vezani uz određenu dob pojedinca (završetak školovanja, zaposlenje, sklapanje braka).

Zemlje srednje i istočne Europe, u koje pripada i Hrvatska, posljednjih tridesetak godina doživljavaju snažan porast udjela starijeg stanovništva i znatne migracije. Glavni uzroci ubrzanoga demografskog starenja jesu porast očekivanog trajanja života i smanjenje fertiliteta. Glavni uzrok migracija značajne su političke, ${ }^{4}$ društvene i gospodarske ${ }^{5}$ promjene kako u nekadašnjim zemljama socijalističkoga društvenog uređenja tako i u Europskoj uniji. Analizirajući starenje i migracije u zemljama srednje i istočne Europe, zamjetno je da su to dva procesa koja se nerijetko međusobno isprepleću i povratno utječu jedan na drugi.

Proces starenja stanovništva započeo je u Hrvatskoj još početkom šezdesetih godina 20. stoljeća, a na njega utječu smanjenje nataliteta, sve dulji život stanovništva, iseljavanje mladih iz ruralnih prostora (značajan utjecaj na bioreprodukciju, koja se »prilagođava « urbanim uvjetima života), kontinuirano iseljavanje $u$ inozemstvo i posredni ratni gubici (Nejašmić i Toskić, 2013: 95). Da je Hrvatska danas zemlja u kojoj živi mnogo starih ljudi, vidljivo je u vizuri svih hrvatskih naselja bez obzira na stupanj njihove urbanosti/ ruralnosti, razvijenosti, prostorni smještaj ili/i veličinu. Demografski, starenje se u posljednjih pedesetak godina može pratiti kroz porast prosječne starosti, koja je 1971. iznosila 34,0 godine (32,4 godine za muškarce, a 35,5 godina za žene), a 2019. je bila 43,6 godine (41,8 za muškarce i 45,3 za žene) (Procjena stanovništva Republike Hroatske u 2019., 2020). Proces starenja ubrzava kontinuirano smanjenje udjela stanovnika u dobi do 19 godina u ukupnom stanovništvu, pa je tako procjena da je 2019. mladih do 19 godina bilo $19,3 \%$, a starih 65 i više godina gotovo 21\% (844.867, od čega čak 506.573 žena) (Procjena stanovništva Republike Hrvatske u 2019., 2020). Prema svim pokazateljima i projekcijama, Hrvatska će i u sljedećih tridesetak godina biti

4 Promjene društveno-političkog, ali i gospodarskog sustava bivših socijalističkih zemalja s jedne strane i širenje Europske unije te time i otvaranje tržišta rada i mogućnost »novih« radnih migracija unutar europskog prostora, ali i veliki valovi izbjeglica zbog ratova na prostoru Bliskog istoka.

5 Posebice ekonomska kriza u prvom desetljeću 21. stoljeća, a neizvjesno je kakve će posljedice na gospodarstva ostaviti dugotrajna pandemija koronavirusa. 
među državama koje će značajno gubiti svoje stanovništvo, a to će pratiti i rast prosječne starosti (UN, 2017).

Uz starenje stanovništva, hrvatsku demografsku stvarnost, cijelo stoljeće značajno određuju i migracije, čiji se uzroci tijekom vremena mijenjaju, a donekle se mijenjaju i smjerovi. Podjednako su to migracije unutar zemlje kao i poslijeratno (Drugi svjetski rat) iseljavanje u inozemstvo do devedesetih godina 20. stoljeća (Nejašmić, 1992, 1996), zatim prisilna seljenja tijekom prve polovine devedesetih (vrijeme ratnih stradanja, prognaništvo i izbjeglištvo) (Živić, 1999) te brojno iseljavanje, najviše mladih ljudi, ali i cijelih obitelji, nakon ulaska Hrvatske u Europsku uniju i otvaranja tržišta rada pojedinih europskih zemalja građanima Hrvatske (Lajić, 2002; Nejašmić, 2014; Klempić Bogadi, Podgorelec i Gregurović, 2018). Upravo zbog starenja ukupnog stanovništva, ali i brojnog iseljavanja građana u radno aktivnoj dobi, nastaju manjkovi u pojedinim gospodarskim granama na tržištu rada, pa Hrvatska posljednjih godina postaje sve više i zemlja useljenja. Valja očekivati da će današnja gospodarska ${ }^{6}$ i razvojna pozicija Hrvatske u odnosu na druge zemlje Europske unije utjecati na daljnje migracije - iseljavanje hrvatskih građana i useljavanje stranaca.

Perspektiva životnog puta posebice je primjenjiva na istraživanja vezana uz procjenu kvalitete života i stupanj integracije imigranata u zemlju primitka (Amit i Litwin, 2010; Amit i Bar-Lev, 2014; Podgorelec, Gregurović i Klempić Bogadi, 2019; Podgorelec, Klempić Bogadi i Gregurović, 2020). Promatra li se Hrvatsku kao useljeničku destinaciju posljednjih šezdesetak godina, uočava se da je bila privlačna međurepublička destinacija od devedesetih, a naročito veliki broj imigranata dolazio je iz ekonomski slabije razvijenih prostora bivše države, posebice iz Bosne i Hercegovine (Klempić Bogadi, Podgorelec i Gregurović, 2018). Promjenom društvenopolitičkog sustava bivše države i osamostaljenjem nekadašnjih republika migracije između Bosne i Hercegovine i Hrvatske dobivaju karakter međudržavnih. I prema popisu stanovništva 2011., u Hrvatskoj je živjelo 584.947 (13,7\%) osoba rođenih u inozemstvu, od čega je čak 70\% (409.357) rođenih u Bosni i Hercegovini. Slijedili su doseljenici rođeni u Srbiji (9\%),

6 Jedan od pokazatelja razlika u kvaliteti života u zemljama Europske unije jest životni standard, kojim se uspoređuju cijene određene robe i usluga u pojedinačnoj zemlji u odnosu na dohodak (BDP) uporabom zajedničke fiktivne valute nazvane standard kupovne moći (SKM). Prema tom, ali i mnoštvu drugih pokazatelja, Hrvatska se nalazi na pretposljednjem mjestu sa 64 boda, iza Rumunjske sa 66, a ispred Bugarske, koja ima 51 bod. Na prvom je mjestu Luksemburg s 261, a na drugom Irska sa 191 bodom (https://europa.eu/ european-union/about-eu/figures/living_hr). 
Njemačkoj $^{7}(5,8 \%)$, na Kosovu (3,5\%), u Sloveniji (3,4\%), Makedoniji $(1,7 \%)$ te u ostalim zemljama (Popis stanovništva, kućanstva i stanova 2011, 2013). Prema migracijskim podacima, Hrvatska od 2011. do 2019. bilježe kontinuirani rast broja doseljenika. Najveći porast je zabilježen 2018. i 2019., kada za razliku od većine prijašnjih godina, među imigrantima dominiraju strani državljani. Tako se 2018. doselilo 26.029 osoba, od kojih je svega 8619 hrvatskih državljana, a 2019. čak 37.726, među kojima je hrvatskih državljana 9882 (Migracije stanovništva Republike Hrvatske..., 2019, 2020). Razlog većeg broja doseljenika, odnosno otvaranja tržišta rada stranim državljanima, povećanje je godišnjih kvota za pojedina zanimanja u primjerice graditeljstvu, turizmu i ugostiteljstvu, prerađivačkoj industriji i prometu. Prema državama porijekla, 2019. iz država članica Europske unije doselilo se 2510 osoba, iz ostalih europskih država 21.684 osobe i 3640 državljana zemalja s drugih kontinenata (najviše iz nekih azijskih zemalja) (Migracije stanovništva Republike Hrvatske u 2019., 2020). Zasad imigranata iz zemalja s drugih kontinenata još uvijek nema mnogo, ali s rastom potreba za određenim zanimanjima na tržištu rada (primjerice $\mathrm{u}$ građevinarstvu u poslovima obnove nakon velikih potresa $\mathrm{u}$ Zagrebu i Sisačko-moslavačkoj županiji, u turizmu i u poslovima skrbi za starije i bolesne) te očekivanim ukidanjem kvota u 2021., situacija će se sigurno mijenjati u smjeru sve brojnijeg doseljavanja radnih migranata. Valja očekivati da to $u$ najvećem broju budu radnici iz, u odnosu na Hrvatsku, slabije ekonomski razvijenih zemalja.

Istraživanje obaju procesa, starenja i migracija, temelj je za određivanje kvalitete života ukupnog stanovništva Hrvatske.

Mnoštvo je definicija kvalitete života (Rapley, 2003), posebice kada se istražuje kvaliteta života određenih društvenih grupa (Hughes, 1990, 1993; Cummins, 1997; Phinney i sur., 2001; Amit i Litwin, 2010). Budući da se rad bavi uporabom perspektive životnog puta $u$ istraživanjima starijih ljudi i migranata, primjerena je definicija World Health Organization Quality of Life (WHOQOL) (1998: 1570), prema kojoj je kvaliteta života »doživljaj/ shvaćanje pojedinčeva položaja u životu u kontekstu kulture i vrijednosnog sustava u kojem živi te $u$ odnosu na njegove osobne ciljeve, očekivanja, standarde i interese«, i Hughes (1993), koja kvalitetu života promatra kao višedimenzionalni koncept mreže povezanih elemenata (pripadnost klasi, rasi, spolu ili dobnoj skupini) čija isprepletenost određuje životne uvjete

7 Mahom druga generacija radnih migranata u Njemačkoj u drugoj polovini 20. stoljeća, rođena u Njemačkoj (Čapo, 2019). 
pojedinaca, pa je tako »i starost varijabla prema kojoj će ljudi različite dobi u istoj kulturi, s različitim povijesnim iskustvom životnih uvjeta i društvenog položaja (koji određuje njihove stavove) kvalitetu života definirati različito (Hughes, 1993: 231).

Cilj rada jest vrednovati prednosti i nedostatke istraživanja starenja (kvalitete života starih ljudi) i migracija (kvalitete života migranata) iz perspektive životnog ciklusa pregledom nekih od važnijih radova koji se time bave.

\section{PERSPEKTIVA ŽIVOTNOG PUTA I STARENJE}

Starenje kao proces najčešće se razmatra u razvojnoj perspektivi, pri čemu je pozornost usmjerena uglavnom na neku vrstu promjena $u$ pojedinca $i$ nerijetko se starost promatra kao izdvojena etapa pojedinčeva života. Starija dob shvaća se kao jedinstveno životno razdoblje u kojem se javljaju specifične promjene i/ili problemi (Perlmutter i Hall, 1992). Termin stara osoba neprecizan je i u većoj mjeri prikriva pravi sadržaj nego što odražava jedinstvenost pojedinačnog života (Dannefer i Sell, 1988). Javna percepcija pojedinaca i skupina koji čine »stare ljude« u pojedinom društvu podložna je stalnoj promjeni. Potvrdilo se da dob nije dovoljan uvjet prema kojem se može ili treba jedinstveno promatrati pojedince međusobno jer razlike rastu s produljenjem života, a i društvene promjene (Holman i Walker, 2020) utječu na promjenu zahtjeva i različita očekivanja ljudi svih dobi (način života i mladih i starih). Tako su danas razlike unutar skupine osoba starijih od 65 godina, a što je arbitrarno određena granica početka starosti, ${ }^{8}$ veće no što su bile nekada, a nerijetko i veće negoli razlike između odraslih mlađih od 65 i starijih od 65 godina (Dannefer i Sell, 1988). Istraživanja (Gunnarsson, 2009) pokazuju da se bez obzira na različitost životnih iskustava starijih ljudi tijekom života i načina na koji žive u starosti (posebice naglašeno s obzirom na različite razine samostalnosti ili ovisnosti: materijalnu, emocionalnu i/ili funkcionalnu) o njima i dalje raspravlja uopćavajući uvjete u kojima žive i potrebu za pomoći/podrškom (obitelji, prijatelja, šire zajednice).

Različiti su teorijski pristupi starijim osobama (Hagestad i Dannefer, 2001), pri čemu se institucionalni pristup u velikoj mjeri bavi socioekonomskim statusom i ulogama starijih, primjerice umirovljenjem (Blane i sur., 2004). Umirovljenje je kompleksan proces oblikovan različitim društvenim prak-

8 Danas, premda se zakoni razlikuju od zemlje do zemlje, najčešće granica za odlazak u punu starosnu mirovinu. Također, jedan je od graničnika za računanje različitih pokazatelja demografskog starenja. 
sama s kojima se pojedinac susreće tijekom života (Wanka, 2019). Najčešće se analizira iz perspektive isključivanja pojedinca povlačenjem iz dotadašnjih društvenih uloga i odgovornosti (kao zaposlenika, odnosno dijela radnog procesa) ili perspektive racionalnog odabira - odlazak u mirovinu kao osobna racionalna odluka temeljena na onome što pojedinac time ostvaruje kao dobitak ili gubitak, najčešće u materijalnom smislu. Kulturna perspektiva nerijetko se bavi negativnim stereotipima vezanim uz starenje i formuliranjem drugačijih pristupa starijima (Hagestad i Dannefer, 2001). Ne bi li se ostvario cjeloviti pristup starenju i starosti, potrebno je integrirati razne perspektive i interpretirati starenje kao odraz međusobno povezanih događanja tijekom života pojedinca: povijesnih, okolinskih i osobnih. Takav kompleksniji pristup koji uključuje promjene i događaje tijekom cjelokupnoga života pojedinca perspektiva je životnog ciklusa (Hareven, 2001) razmatrana unutar određenoga povijesnoga konteksta. Premda je termin široko prihvaćen, neki autori (Giele i Elder, 1998; Edmonston, 2013) objašnjavaju ograničenje termina životni ciklus zalažući se za sintagmu životnog puta. Pritom, životni put objašnjavaju kompleksnim odnosom društveno oblikovanih događaja i preuzetih uloga pojedinca tijekom života, a koji se, prema njihovu shvaćanju, razlikuje od koncepta životnog ciklusa u činjenici da se događaji i uloge koji čine pojedinačno iskustvo života nužno ne nastavljaju u pojedinim etapama života, kako to sama riječ ciklus na neki način određuje. Prema nekima, perspektivom životnog ciklusa češće se koriste ekonomisti (Fuller-Iglesias, Smith i Antonucci, 2009). Ujedno, prema nekima (Elder, 1994, 1998; Giele i Elder, 1998; Elder, Johnson i Crosnoe, 2003; Holman i Walker, 20209), koncept životnog puta širi je jer obuhvaća i objašnjenje povijesnog vremena - događaja i društvenih interakcija koji okružuju pojedinca tijekom života, ali i biološke i psihološke promjene u starosti.

Osim s konceptom životnog ciklusa, perspektivu životnog puta istraživači starenja i kvalitete života starih ljudi (Fuller-Iglesias, Smith i Antonucci, 2009) teorijski uspoređuju s perspektivom trajanja života (life-span perspective), pritom ih ne suprotstavljajući. Obje se zalažu za promatranje starenja kao dugotrajnoga, višedimenzionalnog, kontinuiranog i dinamičnog procesa. Pritom se teorije trajanja života bave procesima i putanjama razvoja i

9 Holman i Walker (2020) posebice su se posvetili povezanosti intersekcionalnosti (međusobno povezanih i preklapajućih društvenih kategorizacija poput pripadnosti rasi, klasi ili spolu /o čemu više u radu Heyse, 2011/, a kojima nastaju međusobno ovisni sustavi diskriminacije i nepovoljnog položaja određenog pojedinca ili skupine u društvu) i perspektive životnog puta koje omogućuju nove uvide u razlike u starenju pojedinaca s posebnim naglaskom na zdravstvenim nejednakostima u starosti. 
starenja kao cjeloživotnog procesa pojedinca, dok se teorije životnog puta bave razlikama u društveno uvjetovanim događajima, promjenama, ulogama i iskustvima u životima pojedinaca (Fuller-Iglesias, Smith i Antonucci, 2009: 3-5) među određenim dijelovima društva (skupinama). Bez obzira na to za koji se termin istraživač odluči, tako definiran pristup proučavanju starenja i starosti omogućava razumijevanje uvjeta u kojima žive stari ljudi objašnjavajući uzorke dobivene i očekivane potpore u starosti kontinuiranom interakcijom promatranog pojedinca s roditeljima, (bračnim) partnerom, djecom i drugima, odnosno članovima društvene mreže, ostvarenima tijekom njegova života. Hareven (2001: 142) to nazivaju »putovanjem [pojedinca] kroz 'povijesno' vrijeme« objašnjavajući da se kvaliteta i način međusobne potpore pojedincu oblikuju tijekom cijelog života pod utjecajem događaja kao što su ratovi, migracije i ekonomska situacija (godine rasta ili krize lokalnih ekonomija).

Svakodnevni život pojedinca objašnjava se procesima i odnosima koji određuju širi kontekst i način na koji ga drugi doživljavaju. Međusobni odnosi s drugim članovima društva igraju značajnu ulogu u načinu života pojedinca, kvaliteti života, bez obzira na njegovu dob ili migracijsko (ne) iskustvo. Perspektiva životnog puta pokušava objasniti utjecaj različitih procesa na skupine ljudi, ali i pojedinačno iskustvo u svakoj životnoj etapi, kao i odnos između događaja iz različitih etapa života (Shanahan i Macmillan, 2008: 13). Pozivajući se na razne studije (Arber i Ginn, 1995; Giele i Elder, 1998), Evy Gunnarsson (2009: 36) zaključuje: »Životni put kao koncept ne pretpostavlja specifičnu teoriju, već daje perspektivu koja može biti početna točka analize starenja kao cjeloživotnog procesa.« Naime, znatne razlike u starenju i načinu života u starosti (kvaliteti života) pokušavaju se objasniti međuodnosom različitih društvenih čimbenika, na prvome mjestu ekonomskim uvjetima: materijalnim stanjem (izvorom i visinom prihoda) (Wanka, 2019), stambenom zbrinutošću (Podgorelec, 2008), vrstom prirodnog okoliša (Podgorelec i Klempić Bogadi, 2013), spolom (Podgorelec i Bara, 2014), etničkom pripadnošću (većinsko ili manjinsko stanovništvo, posebice važno za migracijske prostore, recimo hrvatske otoke /Edmonston, 2013; Podgorelec, Gregurović i Klempić Bogadi, 2019/), stupnjem aktivnosti (Bara i Podgorelec, 2015), stupnjem samostalnosti/ovisnosti s obzirom na očuvanost zdravlja (Fuller-Iglesias, Smith i Antonucci, 2009; Holman i Walker, 2020), korisnošću za obitelj i širu zajednicu, razini uključenosti/isključenosti u zajednici (Podgorelec, 2008; Amit i Litwin, 2010) i dr. Različiti su interesi istraživača za istraživanje kvalitete života u raznim etapama (Blane i sur., 2004). Zbog sve dužeg 
življenja i sve većeg broja jako starih ljudi fokus u istraživanjima kvalitete života usmjerava se više na kvalitetu života ljudi u dubokoj starosti (starije od 90 godina ${ }^{10}$ ), i to najčešće vezano uz zdravstvene probleme te formalne (institucionalne i izvaninstitucionalne) oblike skrbi. Jedan od vrlo korisnih multidisciplinarnih »alata « koji starenju pristupa iz perspektive životnog puta jest, na inicijativu Europske komisije 2004. pokrenuta studija SHARE - Istraživanje o zdravlju, starenju i umirovljenju u Europi. ${ }^{11}$ Studija se provodi u 27 europskih zemalja i Izraelu, a do sada su istraživanjem prikupljeni podaci o zdravlju, socioekonomskom statusu te društvenim i obiteljskim mrežama više od 140.000 osoba u dobi od 50 godina i starijima (Smolić i sur., 2020).

\section{PERSPEKTIVA ŽIVOTNOG PUTA I BIOGRAFSKA METODA}

Istraživanja posljednjih desetljeća pokazuju da razumijevanje starenja i kvalitete života u starosti kao i migracijskih razloga i integracije doseljenika u zemlju primitka zahtijevaju vraćanje subjektivnosti $u$ istraživanje, što je potaknulo znatniji razvoj i uporabu kvalitativnih i interpretacijskih metoda, kao i interes za primjenu biografske perspektive (Birren i sur., 1996; Klempić i Podgorelec, 2002; Amit i Litwin, 2010) te utjecaj fenomenološki orijentirane sociologije (Podgorelec, 2010). Premda je biografski pristup u društvenim istraživanjima prisutan od početka 20. stoljeća, biografsko istraživanje mnogi ne smatraju dijelom određenog polja neke društvene discipline ni ozbiljnom metodom. Biografsku perspektivu pri proučavanju starijih društvene znanosti temelje na simboličkome interakcijskom pristupu Čikaške škole. Još od sedamdesetih godina 20. stoljeća u sociologiji se razvija stav o starenju kao biografskoj karijeri, odnosno određivanju razvoja životnih povijesti i načina na koje one oblikuju život u starosti. Analizirajući važne životne odluke pojedinca i reakcije na događaje tijekom života, ali i praćenje utjecaja društvenih institucija (zaposlenje, obitelj), biografski pristup omogućava bolje razumijevanje starenja. Biografski materijal koji su istraživači prikupljali o mnoštvu pojedinaca oblikovao je pravce razvoja teorija o starenju, pokazao na koji način javni život pojedinca ili zajednice u kojoj živi

10 Zbog sve brojnije skupine jako starih ljudi, a koju od drugih izdvaja, u prvom redu, znatna razlika u tjelesnom i psihičkom zdravlju, istraživači (Schaie i Willis, 2001; Blane i sur., 2004) stare ljude dijele na rano razdoblje starosti (ili mlađe stare, od 60 ili 65 do 75 godina - razdoblje života između prestanka zaposlenosti i početka fizičke ovisnosti), kasnije razdoblje starosti (stariji stari, stariji od 75 do 85 ili 90 godina) te vrlo stare ili najstarije stare - starije od 85 ili 90 godina.

11 Engl. Survey of Health, Ageing and Retirement in Europe. 
utječe na njegov osobni život, a primjenjivao se i za izradu javnih politika kojima se nastojalo utjecati na unapređenje kvalitete života starijih građana (Shanahan i Macmillan, 2008).

Sociolozi jedinstvenost pojedinačnih života nastoje objasniti u okvirima društvenoga konteksta. Omogućuju razlikovanje starih pojedinaca i životnih stilova, pri čemu odgovaraju na zahtjeve društvenih teorija starosti, koje su, prije svega, usmjerene na ono po čemu je svaki pojedinac jedinstven (Gunnarsson, 2009). Potvrđuju starim ljudima osjećaj integriteta i objašnjavaju međugeneracijsku interakciju (Butler, 1963; Atkinson, 1998; Roberts, 2002). Temeljna razlika između biografskog istraživanja i drugih kvalitativnih metoda jest različita uporaba terminâ usmena povijest (životna povijest), osobna naracija (životna priča), biografija i autobiografija te njihova međusobno različita primjena. Prema mnogima (Bryman, 1988; Atkinson, 1998), bit biografske metode jest biografski intervju. U prikupljanju informacija istraživač se pri provođenju biografskog intervjua služi sjećanjem, procjenom i istraživanjem. Coleman (1991: 128-129) naglasio je vezu između socijalne gerontologije, socijalne antropologije i psihologije sjećanja: »Kako ljudi stare i mijenja se perspektiva o prošlosti i budućnosti, mnogi osjećaju potrebu istražiti i objasniti smisao svoje životne priče. (...) Dopustiti osobi mogućnost da glasno, istinski izrazi sebe preduvjet je za postignuće osjećaja kontrole nad životom. « Podjednako je to važno i primjenjivo za doseljenika u novu socijalnu okolinu.

Prema Atkinsonu (1998), životna priča ima strukturu utemeljenu u glavnim etapama većine života: djetinjstvo, školovanje, radno iskustvo, (izvan) bračni život, umirovljenje, umirovljenički život, razdoblje udovištva i sl., u životnim događajima (rođenje, vjenčanje, razvod, migracija, smrt) i orijentacijama (vrijednostima i vjerovanjima) i stoga je temeljna metoda u pristupu životnog puta. Navedeni glavni događaji, etape ili graničnici važni su i za promatranje pojedinčeva života u određenom razdoblju (starosti) ili u vezi s nekom odlukom (o migriranju) kroz perspektivu životnog puta. Pritom se struktura života, slijed događaja ne određuje unaprijed - planiranim pitanjima $u$ intervjuu, nego je naknadno, prezentacijom u pisanom obliku, određuje istraživač.

Takva definicija životne priče naslanja se na definiciju Shanahan i Macmillan (2008: 40-41), prema kojoj je životni put pojedinca na svojevrstan način »dobno i društveno stupnjevan«, pri čemu se uloge i događaji tijekom raznih razdoblja života odvijaju i mijenjaju na predvidljiv način s vremenom. Dakle, perspektiva životnog puta određuje pojedinčevu biografiju kao di- 
namičnu društvenu konstrukciju (Klempić Bogadi i Podgorelec, 2014). na koju utječu društvene institucije i drugi pojedinci omogućavajući ili ograničavajući društvene uloge koje živimo u pojedinoj etapi života.

\section{PERSPEKTIVA ŽIVOTNOG PUTA I MIGRACIJE}

Migranti se na seljenje odlučuju u različitoj dobi i potaknuti različitim razlozima (Kennan i Walker, 2013). Seljenje je proces koji utječe na obje društvene okoline - porijekla migranta i okolinu doseljenja, pa i onda ako se migrant seli unutar neke zemlje i uz pretpostavku da društvene i kulturne razlike između mjesta preseljenja nisu znatne (Amit, 2012; Podgorelec, Gregurović i Klempić Bogadi, 2019).

Autori, baveći se raznim temama pri istraživanju mobilnosti stanovništva, razlikuju unutarnje migracije (Čipin, Strmota i Međimurec, 2016; Finney i Marshall, 2018) i seljenje preko državnih granica (Edmonston, 2013). S obzirom na perspektivu životnog puta migranata pregledna je klasifikacija istraživačkih tema G. Jasso (2003: 334), koja ih je grupirala u: karakteristike migranata pri doseljenju, a koje utječu na prilagodbu - dob, spol, zemlja podrijetla, razina obrazovanja (Finney i Marshall, 2018; Podgorelec, Klempić Bogadi i Gregurović, 2020); stupanj uspješnosti - od asimilacije, akulturacije i prilagodbe do integracije u društvo primitka (Berry, 1990; Amit, 2012; Amit i Bar-Lev, 2014; Podgorelec, Gregurović i Klempić Bogadi, 2019) odnosno neuspješnosti - odustajanje i povratak u zemlju podrijetla ili seljenje u treću zemlju; uspjeh migranata u dječjoj dobi ili druge generacije migranata (djetinjstvo i školovanje u zemlji doseljenja) (Pivovarova i Powers, 2019); demografski i ekonomski učinci na društva podrijetla i primitka - studije gubitka i dobitka (seljenje kvalificiranih migranata, umjetnika, poduzetnika) (Gregurović, 2019), doznake (Nzima, Duma i Moyo, 2017) i sl.

Edmonston (2013: 3) oslanja se u objašnjenju prednosti uporabe perspektive životnog puta $u$ istraživanjima (i)migracije na radove jednog od vodećih teoretičara perspektive životnog puta Glena Eldera $(1994,1998)$. Pritom povezuje četiri teme koje Elder inače drži ključnima pri analizi životnog puta: međusobna povezanost pojedinačnih života i povijesnog vremena, planiranje i odabir bitnih događaja $u$ životu pojedinca, povezanost pojedinčeva života s drugima (obitelj, prijatelji i radna okolina) i djelovanje društvenih institucija (učinak) tijekom života. Već na prvi pogled uočava se povezanost općenitog pristupa analize životnog puta (Elder, 1994, 1998) s već navedenim skupinama tema pri istraživanju migracija (Jasso, 2003). Svaku od tema moguće je poduprijeti raznim primjerima i u hrvatskom društvu. 
Tako, budući da povijesno vrijeme i aktualne društvene promjene oblikuju stavove društva prema migrantima, primjerice s manjkom radnika u određenim gospodarskim granama ${ }^{12}$ na hrvatskom tržištu mijenja se zakonska regulativa za zapošljavanje stranaca, ali i odnos domicilnog stanovništva prema doseljenicima. Također, u malim demografski ugroženim otočnim zajednicama stanovnici su otvoreni prema trajnom doseljavanju neotočana zbog straha od izumiranja (Podgorelec i Klempić Bogadi, 2013). Na planiranje i odabir bitnih događaja poput odluke o tome kada se seliti (životni tajming) značajno utječu dva demografska aspekta: dob migranata i dužina nastanjenja u zemlji primitka. Uz razna ograničenja koje pojedine zemlje određuju za useljenike (primjerice Kanda - dob useljenika, Edmonston, 2013), istraživanja potvrđuju da se češće sele, sami ili s obitelji, mlađi odrasli. Tako su, kada je riječ o Hrvatskoj, Čipin, Strmota i Međimurec (2016) pišući o procjeni cjeloživotne prostorne pokretljivosti stanovništva unutar Hrvatske iz perspektive životnoga ciklusa ${ }^{13}$ došli do sljedećih zaključaka: distribucija seljenja neujednačena je tijekom života, žene su sklonije seljenju, očekivana migracija s porastom dobi postupno se smanjuje, a najčešće se sele, kao što su pokazale i druge studije, mladi odrasli, pa je, prema njihovu izračunu, vrhunac intenziteta unutarnjih migracija pojedinaca tijekom dvadesetih godina života. Ipak, autori zaključuju da je u usporedbi s drugim zemljama unutarnja mobilnost stanovništva u Hrvatskoj niska, što objašnjavaju, između ostaloga, problemima rješavanja stambenoga pitanja te ekonomskim i društvenim prilikama u zemlji. Povezanost pojedinčeva života s drugima koncept je koji naglašava povezanost migranata s obitelji, prijateljima, susjedima i društvenom mrežom, koji pomažu pri iseljavanju iz zemlje podrijetla (sponzoriranje migracije i sl.) ili pak pri doseljavanju u zemlju primitka (Finney i Marshall, 2018; Podgorelec, Gregurović i Klempić Bogadi, 2019; Podgorelec, Klempić Bogadi i Gregurović, 2020). Djelovanje pojedinca odnosno odluka za seljenje ovise o utjecaju društvenih institucija tijekom raznih životnih etapa, o migracijskim politikama u zemlji podrijetla i zemlji primitka koje određuju »poželjne« karakteristike doseljenika - dob, spol, obrazovanje, znanje jezika i sl. (Amit i Litwin, 2010; Amit i Bar-Lev, 2010, 2014; Amit, 2012).

Objašnjavajući ulogu specifičnosti migrantskih života, Edmonston (2013: 4-6) predlaže klasifikaciju životnog puta u šest etapa: djetinjstvo, mladost, razdoblja mlađe odrasle osobe, srednje odrasle osobe, starije odrasle osobe

12 U Uvodu su navedeni turizam ili građevinarstvo (posebice sada nakon velikih potresa).

13 Budući da su autori ekonomisti, bliža im je definicija perspektive životnog ciklusa. 
i starost, koje povezuje s osam društvenih institucija koje utječu na živote migranata. To su u prvoj - političkoj, sferi, posebice imigracijskoj životnoj priči, stjecanje državljanstva te razne vrste civilnog i političkog djelovanja (Podgorelec, Gregurović i Klempić Bogadi, 2019), a u drugoj- vjerskoj, prilagodba i eventualne promjene u prakticiranju religije. Treća je obiteljska ili međugeneracijska razmjena kao temeljni aspekt uspješnosti prilagodbe migranata, a suvremena istraživanja sve se više bave transnacionalnim obiteljima i položajem transnacionalnih generacija (Čapo, 2019). Četvrta je zaposlenje i/ili zanimanje kao pokazatelj ekonomskog temelja uspješnosti migranata, a peta prihod kao važan pokazatelj (ne)jednakosti i ekonomske prilagodbe migranata (Blane i sur., 2004). Šesta je školovanje i jezična kompetentnost, odnosno, uz službeni jezik zemlje primitka, znanje drugog ili trećeg jezika kao dodatna mogućnost pri kasnijem razvoju karijere (Podgorelec, Gregurović i Klempić Bogadi, 2019), sedma stanovanje i stambena mobilnost kao pokazatelj razine integracije i uključenosti u društvo primitka (Murdi i Ghosh, 2010; Podgorelec, Klempić Bogadi i Gregurović, 2020), a osma zdravlje kao pokazatelj nejednakosti u ranijim fazama migracije zdravstvena selekcija prilikom useljavanja te nakon određenog vremena smanjenje zdravstvenih razlika i sl. (Podgorelec, 1990; Finney i Marshall, 2018). Pritom naglašava da ovakvom klasifikacijom nije iscrpljena sva kompleksnost istraživanja migracija i kvalitete života raznih migrantskih skupina, odnosno njihovih životnih priča.

\section{UMJESTO ZAKLJUČKA}

Cilj rada bio je, na pregledan način, vrednovati perspektivu životnog puta kao teorijski i praktični pristup starenju (kvaliteti života starih ljudi) i raznim vrstama migracija (kvaliteti života migranata). Kvaliteta života društva ovisi o kvaliteti života pojedinaca i raznih društvenih skupina, među kojima su uvijek i ranjive skupine. Pregledom dijela literature posvećene starenju i migracijama moguće je zaključiti da, premda temeljno odvojeni procesi, promatrani iz perspektive životnog puta, dijele slične putanje, prijelaze, prekretnice i vrijeme (Edmonston, 2013). Tako istraživanja kvalitete života starih ljudi moraju biti utemeljena u teorijskoj konstrukciji starenja i povijesnom kontekstu, oslanjajući se na prikupljene podatke o bitnim životnim događajima pojedinca (životnoj priči) i prosudbama iskustava, kako ispitanika tako i istraživača. Perspektiva životnog puta kojom se mjeri utjecaj društvenih, političkih i ekonomskih uvjeta na život pojedinca i/ili skupine zanimljiv je i kompleksan pristup istraživanju odabranih dimen- 
zija kvalitete života migranata, s obzirom na to da se migracije uvijek odvijaju u određenome povijesnom kontekstu utječući na društvenu okolinu - zemlje podrijetla i zemlje primitka. Javne politike koje podupiru organizaciju skrbi starijih ljudi i olakšavaju prilagodbu te unapređuju integraciju migranata, harmoniziraju sve dijelove društva i utječu na zadovoljstvo životom ukupnog stanovništva. Iskustva zemalja koje su to zanemarile ne treba ponavljati.

\section{LITERATURA}

Akrap, A. i Čipin, I. (2006). Socijalitetni sterilitet u Hrvatskoj-zašto smo neoženjeni i neudane. Zagreb: Ministarstvo obitelji, branitelja i međugeneracijske solidarnosti.

Amit, K. i Litwin, H. (2010). The Subjective Well-Being of Immigrants Aged 50 and Older in Israel, Social Indicators Research, 98 (1): 89-104. https://doi.org/10.1007/s112050099519-5

Amit, K. (2012). Social integration and identity of immigrants from western countries, the FSU and Ethiopia in Israel, Ethnic and Racial Studies, 35 (7): 1287-1310. https://doi. org/10.1080/01419870.2011.602091

Amit, K. i Bar-Lev, S. (2010). Identity construction of highly skilled FSU and Western immigrants in Israel: the case of high-tech workers. Annual conference of the CanadaIsrael Bilateral Forum on Migration. Ruppin Academic Center.

Amit, K. i Bar-Lev, S. (2014). Immigrants' Sense of Belonging to the Host Country: The Role of Life Satisfaction, Language Proficiency, and Religious Motives, Social Indicator Research, 124 (3): 947-961. https://doi.org/10.1007/s11205-014-0823-3

Atkinson, R. (1998). The Life Story Interview. London: Sage Publications.

Bara, M. i Podgorelec, S. (2015). Društvene teorije umirovljenja i produktivnog starenja, Etnološka tribina, 45 (38): 38-58. https://doi.org/10.15378/1848-9540.2015.38.02

Berry, J. W. (1990). Psychology of acculturation, u: J. Berman (ur.). Cross-Cultural Perspectives: Nebraska Symposium on Motivation. Lincoln: University of Nebraska Press, 201-234.

Birren, J. E., Kenyon, G. M., Ruth, J-E., Schroots, J. J. F. i Svenson, T. (ur.) (1996). Aging and Biography: Exploration in Adult Development. New York: Springer.

Blane, D., Higgs, P., Hyde, M. i Wiggins, R. D. (2004). Life course influence on quality of life in early old age, Social Science $\mathcal{E}$ Medicine, 58 (11): 2171-2179. https://doi. org/10.1016/j.socscimed.2003.08.028

Börsch-Supan, A., Brandt, M., Hunkler, C., Kneip, T., Korbmacher, J., Malter, F., Schaan, B., Stuck, S. i Zuber, S. (2013). Data Resource Profile: The Survey of Health, Ageing and Retirement in Europe (SHARE), International Journal of Epidemiology, 42 (4): 9921001. https://doi.org/10.1093/ije/dyt088

Bryman, A. (1988). Quantity and Quality in Social Research. London: Unwin Hyman.

Coleman, P. G. (1991). Ageing and Life History: the Meaning of Reminiscence in Late Life, u: Dex, S. (ur.). Life and Work History Analyses. London: Routledge, 120-143.

Cummins, R. (1997). Assessing Quality of Life for People with Disabilities, u: Brown, R. I. (ur.). Quality of Life for Handicapped People. Cheltenham: Stanley Thomas, 116-150. 
Čapo, J. (2019). Dva doma - Hrvatska radna migracija u Njemačkoj kao transnacionalni fenomen. Zagreb: Durieux.

Čipin, I., Strmota, M. i Međimurec, P. (2016). Mobilnost stanovništva u Hrvatskoj iz perspektive životnoga ciklusa, Migracijske i etničke teme, 32 (1): 9-35. https://doi. org/10.11567/met.32.1.1

Dannefer, D. i Sell, R. R. (1988). Age structure, the life course and "aged heterogeneity": prospects for research and theory, Comprehensive Gerontology B, 2 (1): 1-10.

Dannefer, D. i Miklowski, C. (2006). Development in the Life Course, u: Vincent, J. A., Phillipson, C. R. i Downs, M. (ur.). The Futures of the Old Age. London: Sage Publications, 30-40. http://dx.doi.org/10.4135/9781446211533.n3

Edmonston, B. (2013). Life course perspectives on immigration, Canadian Studies in Population, 40 (1-2): 1-8. https://doi.org/10.25336/P6MK73

Elder, G. H. (1994). Time, Human Agency, and Social Change: Perspectives on the Life Course, Social Psychology Quarterly, 57 (1): 4-15. https://doi.org/10.2307/2786971

Elder, G. H. (1998). The Life Course and Development Theory, Child Development, 69 (1): 1-12. https://doi.org/10.1111/j.1467-8624.1998.tb06128.x

Elder, G. H., Johnson, M. K. i Crosnoe, R. (2003). The Emergence and Development of Life Course Theory, u: Mortimer, J. T. i Shanahan, M. J. (ur.). Handbook of the Life Course. New York: Kluwer Academic Publishers, 3-19. https://doi.org/10.1007/9780-306-48247-2_1

Finney, N. i Marshall, A. (2018). Is migration in later life good for wellbeing? A longitudinal study of ageing and selectivity of internal migration, Area, 50: 492-500. https://doi.org/10.1111/area.12428

Fuller-Iglesias, H., Smith, J. i Antonucci, T. C. (2009). Theories of Aging From a LifeCourse and Life-Span Perspective - An Overwiew, Annual Review of Gerontology \& Geriatrics, 29 (1): 3-25.

Giele, J. Z. i Elder, G. H. (1998). Life Course Research: Development of a Field, u: Giele, J. Z. i Elde, G. H. (ur.). Methods of Life Course Research: Qualitative and Quantitative Approaches. Thousand Oaks: SAGE Publishing, 5-27. https://doi.org/10.4135/ 9781483348919.n1

Glick, P. C. (1988). Fifty Years of Family Demography: A Record of Social Change, Journal of Marriage and Family, 50 (4): 861-873. https://doi.org/10.2307/352100

Hareven, T. K. (2001). Historical Perspectives on Aging and Family Relations, u: Binstock, R. H. i George, L. (ur.). Handbook of Aging and the Social Sciences. San Diego: Academic Press, $141-155$.

Gregurović, S. (2019). The Impact of EU Citizenship on Migrant Integration. The Case of Highly Skilled Migrants from Southeast Europe in Brussels, Etnološka tribina, 49 (42): 102-121. https://doi.org/10.15378/1848-9540.2019.42.03

Gunnarsson, E. (2009). 'I think I have had a good life': the everyday lives of older women and man from a lifecourse perspective, Aging and Society, 29: 33-48. https://doi. org/10.1017/S0144686X08007642

Hagestad, G. O. i Dannefer, D. (2001). Concepts and Theories of Aging: Beyond Microfication in Social Science Approaches, u: Binstock, R. H. i Geoerge, L. K. (ur.). Handbook of Aging and the Social Sciences. San Diego: Academic Press, 3-21.

Heyse, P. (2011). Perspektiva životnog toka u analizi vlastitog iskustva migrantica u Belgiji - primjer Ukrajinki i Ruskinja u Belgiji, Migracijske i etničke teme, 27 (2): 199 -225. 
Holman, D. i Walker, A. (2020). Understanding unequal ageing: towards a synthesis of intersectionality and life course analyses, European Journal of Ageing, https://doi. org/10.1007/s10433-020-00582-7

Hughes, B. (1990). Quality of life, u: Peace, S. M. (ur.). Researching Social Gerontology Concepts, Methods and Issues. London: Sage Publications, 46-58.

Hughes, B. (1993). Gerontological Approaches to Quality of Life, u: Johnson, J. i Slater, R. (ur.). Aging and Later Life. London: Sage Publications, 233-238.

Jasso, G. (2003). Migration, Human Development, and the Life Course, u: Mortimer, J. T. i Shanahan, M. J. (ur.). Handbook of the Life Course. New York: Kluwer Academic Publishers, 331-364.

Johnson, J. i Slater, R. (ur.) (1993). Aging and Later Life. London: Sage Publications.

Kennan, J. i Walker, J. R. (2013). Modeling individual migration decisions, u: A. F. Constant i K. F. Zimmermann (ur.). International Handbook on the Economics of Migration. Cheltenham: Edward Elgar Publishing 39-54.

Klempić, S. i Podgorelec, S. (2002). Utjecaj migracija na starenje otočnog stanovništva pet iških priča, Migracijske i etničke teme, 18 (4): 319-338.

Lajić, I. (2002). Hrvatske migracije početkom 21. stoljeća, Migracijske i etničke teme, 18 (2-3): $135-149$.

Murdi, R. i Ghosh, S. (2010). Does spatial Concentracion Always Mean a Lack of Integration? Exploring Ethnic Concentracion and Integration in Toronto, Journal of Ethnic and Migration Studies, 36 (2), 293-311. https://doi.org/10.1080/ 13691830903387410

Nejašmić, I. (1992). Osnovne značajke unutarnje migracije stanovništva Hrvatske 18801981, Migracijske i etničke teme, 8 (2): 141-166.

Nejašmić, I. (1996). Hrvatski građani na radu u inozemstvu i članovi obitelji koji s njima borave prema popisu 1991: prikaz prema novom teritorijalnom ustrojstvu jedinica lokalne samouprave, Migracijske i etničke teme, 12 (3): 205-218.

Nejašmić, I. i Toskić, A. (2013). Starenje stanovništva u Hrvatskoj - sadašnje stanje i perspektive, Hrvatski geografski glasnik, 75 (1): 89 -110.

Nejašmić, I. (2014). Iseljavanje iz Hrvatske od 1900. do 2001.: demografske posljedice stoljetnog procesa, Migracijske i etničke teme, 3 (3), 405-435. https://doi.org/10.11567/ met.30.3.6

Nzima, D., Duma, V. i Moyo, P. (2017). Migration and Local Development: The Multiplier Effect of Migrant Remittances on Non-recipient Households in Tsholotsho, Zimbabwe, Migracijske i etničke teme, 33 (2): 143-164. https://doi. org/10.11567/met.33.2.2

Klempić Bogadi, S. i Podgorelec, S. (2014). Active ageing as lifestyle on Croatian islands, Zbornik Matice srpske za društvene nauke, 65 (3): 715-725. https://doi.org/10.2298/ zmsdn1448715k

Klempić Bogadi, S., Gregurović, M. i Podgorelec, S. (2018). Doseljavanje iz Bosne i Hercegovine u Hrvatsku: migracijski obrasci doseljenika u Zagrebu, Stanovništvo, 56 (2): 39-62. https://doi.org/10.2298/STNV1802039K

Perlmutter, M. i Hall, E. (1992). Adult Development and Aging. New York: John Wiley \& Sons, Inc.

Phinney, J., Horenczyk, G., Liebkind, K. i Vedder, P. (2001). Ethnic identity, Immigration, and Well-Being: An Interactional Perspective, Journal of Social Issues, 57 (3): 493-510. https://doi.org/10.1111/0022-4537.00225 
Pivovarova, M. i Powers, J. M. (2019). Generational status, immigrant concentration and academic achievement: first and second-generation immigrants with third-plus generation students, Large-scale Assessments in Education, 7: 7. https://doi.org/10.1186/ s40536-019-0075-4

Podgorelec, S. (1990). Migracije i zdravlje, Migracijske teme, 6 (4): 69-79.

Podgorelec, S. (2008). Ostarjeti na otoku - Kvaliteta života starijega stanovništva hrvatskih otoka. Zagreb: Institut za migracije i narodnosti.

Podgorelec, S. (2010). Migracija kao sudbina - hrvatski otoci i starenje stanovništva, u: Lajić, I. (ur.). Migracije i regionalni razvoj. Zagreb: Institut za migracije i narodnosti, $141-162$.

Podgorelec, S. i Klempić Bogadi, S. (2013). Gradovi potopili škoje - promjene u malim otočnim zajednicama. Zagreb: Institut za migracije i narodnosti.

Podgorelec, S. i Bara, M. (2014). Žensko iskustvo migracija i starenja - pogled s otokâ, Migracijske i etničke teme, 30 (3): 379-404. https://doi.org/10.11567/met.30.3.5

Podgorelec, S., Gregurović, M. i Klempić Bogadi, S. (2015). Satisfaction with the quality of life on Croatian small islands: Zlarin, Kaprije and Žirje, Island Studies Journal, 10 (1): 91-110.

Podgorelec, S., Gregurović, M. i Klempić Bogadi, S. (2019). Immigrants from Bosnia and Herzegovina in Croatia: A Sense of Belonging and Acceptance in the New Social Environment, Razprave in gradivo, 82 (1): 5-23.

Podgorelec, S., Klempić Bogadi, S. i Gregurović, M. (2020). Stambena integracija imigranata iz $\mathrm{BiH}$ u Hrvatskoj: primjer Grada Zagreba/Housing Integration of Immigrants from Bosnia and Herzegovina in Croatia: Example of the City of Zagreb, Geoadria, 25 (1): 8-28. https://doi.org/10.15291/geoadria.2891

Rapley, M. (2003). Quality of Life - A Critical Introduction. London: Sage Publications.

Roberts, B. (2002). Biographical Research. Buckingham - Philadelphia: Open University Press.

Schaie, W. K. i Willis, S. L. (2001). Psihologija odrasle dobi i starenja. Jastrebarsko: Slap.

Shanahan, M. J. i Macmillan, R. (2008). Biography and the Sociological Imagination-Contexts and Contingencies. New York - London: W.W. Norton \&Company.

Smolić, Š., Čipin, I., Fabijančić, M. i Mustač, D. (2020). Implementacija i metodološki okvir studije SHARE u Hrvatskoj, Migracijske i etničke teme, 36 (1): 29-52. https://doi. org/10.11567/met.36.1.2

Živić, D. (1999). Promjene u dinamici i razmještaju prognaničko-izbjegličkog kontingenta u Republici Hrvatskoj od sredine 1991. do sredine 1998. godine, Društvena istraživanja, (5-6): 767-791.

Wanka, A. (2019). Change Ahead - Emerging Life-Course Transition as Practical Accomplishments of Growing Old(er), Frontiers in Sociology, 3: 45. https://doi. org $/ 10.3389 /$ fsoc. 2018.00045

UN (2017). World Population Prospects: 2017 The Revision. New York: Department of Economic and Social Affairs.

World Health Organization Quality of Life Group (1998). The World Health Organization Quality of Life assessment (WHOQL): Development and general psychometric properties, Social Science and Medicine, 46 (12): 1569-1585. https://doi.org/10.1016/ S0277-9536(98)00009-4 


\section{IZVORI}

Popis stanovništva, kućanstva i stanova 2011, Državni zavod za statistiku, Zagreb, 2013. www.dzs.hr

Procjena stanovništva Republike Hrvatske u 2019., Priopćenje 7.1.3., Državni zavod za statistiku, Zagreb, 2020, https://www.dzs.hr/hrv_eng/publication/2020/07-01-03_ 01_2020.htm

Živjeti u EU-u, Eurostat, https://europa.eu/european-union/about-eu/figures/living_hr

Migracije stanovništva Republike Hrvatske u 2018., Priopćenje 7.1.2., Državni zavod za statistiku, Zagreb, 2019, https://www.dzs.hr/Hrv_Eng/publication/2019/07-01-02_ 01_2019.htm

Migracije stanovništva Republike Hrvatske u 2019., Priopćenje 7.1.2., Državni zavod za statistiku, Zagreb, 2020, https://www.dzs.hr/Hrv_Eng/publication/2020/07-01-02_ 01_2020.htm

\section{Research on Aging and Migration from the Perspective of Life-Course}

\section{Sonja Podgorelec}

\section{SUMMARY}

A life-course perspective is a complex approach to researching the life of an individual or group or certain processes used in various disciplines (Börsch-Supan et al., 2013), especially in sociology, demography, psychology, and economics. The life course perspective seeks to connect the historical context that determines an individual's life with personal history (key events of his or her life) (Edmonston, 2013; Holman and Walker, 2020). The paper explains the differences among how the life-course perspective, lifecycle perspective and life-span perspective approach research topics.

More specifically, this paper aims to evaluate the advantages and disadvantages of research on aging (quality of life of older people) and migration (quality of life of migrants) from the perspective of life course by reviewing some of the most important papers addressing it, both theoretically and/or practically.

In the first of the five chapters of the paper, Introduction, the author explains why the perspective of life course is an interesting research approach to selected topics in Croatia. Together with the other countries of Central and Eastern Europe, Croatia has experienced a strong increase in the share of the elderly population and significant migration in the last thirty or so years. The major causes of accelerated demographic aging are an increase in life expectancy and a decrease in fertility. The main causes of migration are significant political, social and economic changes in the "old" and "new" EU countries. These are changes in the socio-political and economic systems of the former socialist countries on the one hand, and the expansion of the EU resulting in the opening of the labour market and the possibility of "new" labour migration within Europe on the other. Due to the wars in the Middle East, there is also the issue of dealing with large refugee waves. 
The life-course perspective is particularly applicable to research on population aging, the assessment of the quality of life and the degree of integration of immigrants in the destination country.

The second chapter, Life Perspective and Aging, explains various theoretical approaches to older people (Hagestad and Dannefer, 2001). The institutional approach largely addresses the socio-economic status and roles of the elderly, for example, retirement (Blane et al., 2004; Wanka, 2019). The cultural perspective often deals with negative stereotypes related to aging and formulating different approaches to the elderly (Hagestad and Dannefer, 2001). In order to achieve a holistic approach to aging and old age, various perspectives should be integrated, and aging should be interpreted as a reflection of interrelated events during an individual's life: historical, environmental and personal. Such a more complex approach involving changes and events throughout an individual's life is a life cycle perspective (Godley and Hareven, 2001) considered within a particular historical context. Although it is widely accepted, some authors (Giele and Elder, 1998; Edmonston, 2013) explain the limitation of the term "life cycle" by advocating the phrase "life course". In doing so, they explain life course as a complex relationship between socially shaped events and the roles an individual assumes during life. According to them, this differs from the concept of a life cycle in that the events and roles that make up an individual life experience do not necessarily continue at certain stages of life, as is suggested by the word "cycle".

In addition to the concept of a life cycle, researchers of aging and the quality of life of older people (Fuller-Iglesias, Smith and Antonucci, 2009) also theoretically compare the perspective of life course and the life span perspective without opposing them. Both advocate a view of aging as a long-lasting, multidimensional, continuous, and dynamic process. Life theories deal with the processes and pathways of development and aging as a lifelong process of an individual while life theories deal with differences in socially conditioned events, changes, roles and experiences in the lives of individuals (Fuller-Iglesias, Smith and Antonucci, 2009: 3-5) among certain parts of society (groups). An individual's daily life is explained by processes and relationships that determine the broader context and how others experience it. Interpersonal relationships with other members of society play a significant role in an individual's lifestyle and quality of life, regardless of his or her age or migration (in)experience. The life course perspective seeks to explain the impact of different processes on groups of people and individual experiences at each life stage but also the relationship between events from different stages of life.

The third chapter, Life Perspective and Biographical Method, discusses the need to return to more significant use of qualitative and interpretative methods, as well as the interest in using a biographical perspective, due to a better understanding of aging and quality of life in old age as well as migration reasons and integration of immigrants in the country of immigration. By telling their life story, a person clarifies the personal understanding of changes in the immediate (personal circle) and the wider environment (society). They also describe how individual members of the group to which the individual feels affiliated, for example, the generation of older people in a particular environment (islands) (Podgorelec, 2008) or immigrants, experienced changes in society during life (older people) or a personal migrant experience and to what extent the changes experienced affect their lives (Amit and Litwin, 2010; Podgorelec, Gregurović and Klempić Bogadi, 2019).

Biographical research is especially useful in monitoring the development of an individual's career, the impact of migration (on a personal level, but also in terms of 
community development), the way people face new experiences and changes during aging or migration and how they adapt (especially to various losses: employment, health and functional status, life partners, friends etc.).

The fourth chapter, Life and Migration Perspective, explains certain characteristics of migration and migrants, especially when moving to the country of immigration. Thus, Jasso (2003: 334) grouped them into characteristics that affect adaptation - age, gender, country of origin, level of education (Finney and Marshall, 2018; Podgorelec, Klempić Bogadi and Gregurović, 2020); degree of success - from assimilation, acculturation and adaptation to integration into the receiving society (Berry, 1990; Amit, 2012; Amit and Bar-Lev, 2014; Podgorelec, Gregurović and Klempić Bogadi, 2019) or failure - giving up and returning to the country of origin or moving to a third country; the success of migrants in childhood or the second generation of migrants (childhood and schooling in the country of immigration) (Pivovarova and Powers, 2019); demographic and economic effects on societies of origin and immigration - studies of loss and gain (relocation of qualified migrants, artists, entrepreneurs) (Gregurović, 2019), remittances (Nzima, Duma and Moyo, 2017), etc.

Migrants choose to move at various ages and are motivated by various reasons (Kennan and Walker, 2013). Migration is a process that affects both social environments - that of the origin of the migrant as well as the immigration environment, even if the migrant migrates within a certain country (Čipin, Strmota and Međimurec, 2016; Finney and Marshall, 2018) and assuming that social and cultural differences between places of resettlement are not significant (Amit, 2012; Podgorelec, Gregurović and Klempić Bogadi, 2019). Edmonston (2013: 3) relies on the work of Elder (1994, 1998) in explaining the benefits of using a life-course perspective in (im)migration research. He connects four topics that Elder considers crucial in the analysis of life course: the interconnectedness of individual lives and historical time, planning and selection of important events in an individual/s life, the connection of an individual's life with others (family, friends, work environment) and action (effect) of social institutions during life. The connection between the general approach to the life course analysis (Elder, 1994, 1998) and the previously mentioned groups of topics in migration research is noticeable already at the first glance (Jasso, 2003). Each of the topics can be supported by various examples in Croatian society.

In the last chapter, instead of a conclusion, the author states that by reviewing a part of the literature on aging and migration, it is possible to deduce that, although fundamentally separate processes, observed from a life-course perspective, they share similar trajectories, transitions, turning points and timing (Edmonston, 2013). Thus, research into the quality of life of older people must be grounded in the theoretical construction of aging and the historical context, relying on collected data on the individual's important life events (life story) and judgments of experiences by both respondents and researchers. A life-course perspective that measures the impact of social, political and economic conditions on the life of an individual and/or a group is an interesting and complex approach to researching selected dimensions of migrants quality of life, given that migration always takes place in a particular historical context by influencing the social environment - countries of origin and countries of immigration. Public policies that support the organisation of care for the elderly, facilitate adaptation and promote the integration of migrants harmonise all sections of society and affect the life satisfaction of the general population.

KEY WORDS: life-course perspective, aging, migration, life story 